\title{
Benoît Godin
}

\section{0 początkach bibliometrii*}

STRESZCZENIE. Pośród wielu statystyk dotyczących nauki, nazywanych naukometrią, bibliometria zajmuje szczególne miejsce. Jest jedną z niewielu poddziedzin, skupiających się na mierzeniu wytwórczego wymiaru nauki. Zgodnie z większością „historii” bibliometria zawdzięcza swój systematyczny rozwój przede wszystkim D.J. de Solla Price’owi i Eugene’owi Garfieldowi, jej twórcom. Kilka prac wykonanych przed latami 50. XX wieku przeważnie umieszcza się w prehistorii. Niniejszy artykuł dowodzi, że systematyczne liczenie publikacji zaczęło się od psychologów. Na początku XX wieku zaczęli oni zbierać statystyki dotyczące swojej dyscypliny. Przez kilka dekad na poczet publikacji zaliczano przemówienia, recenzje i spisane historie psychologii. Celem zaś było przyczynienie się do rozwoju tej dziedziny. Zarówno rozmiar, jak i systematyczność tych wysiłków, niedające się sprowadzić do nieznaczących osiągnięć natury prehistorycznej, są dowodami na pionierski charakter tej pracy, zaś jej autorów należy uznać za prekursorów bibliometrii.

SŁOWA KLUCZOWE: bibliometria, naukometria, historia nauki, publikacje naukowe

\section{Wstęp}

To amerykańskiemu psychologowi, Jamesowi McKeenowi Cattellowi, redaktorowi Science w latach 1895-1944, zawdzięczamy pierwszy usystematyzowany zbiór statystyk dotyczących nauki (Godin 2007). W 1906 r. Cattell zaczął opracowywać spis biograficzny American Men of Science, wydawany co pięć lat. Spis zawierał informacje na temat tysięcy aktywnych badawczo naukowców w Stanach Zjedno-

* Praca ukazała się oryginalnie jako: Godin, B. (2007). On the origins of bibliometrics. Scientometrics. 68(1): 109-133. Dziękujemy autorowi za zgodę na tłumaczenie. 
czonych. Na podstawie danych Cattell prowadził regularne i systematyczne badania statystyczne nauki aż do lat 30. XX wieku. Stworzył statystyki dotyczące wielu naukowców, ich rozmieszczenia geograficznego i szeregował ich według osiągnięć. Cattellowi można przypisać rozpoczęcie naukometrii czy też systematycznych pomiarów nauki.

Cattell wprowadził dwa wymiary do pomiarów nauki, które do dziś definiują to pole: ilość i jakość. Ilość, czy też produktywność, jak sam ją nazywał, polegała na prostym zliczaniu naukowców w skali kraju. Jakość, czy też efektywność, definiował z kolei jako wkład w rozwój nauki i mierzył ją za pomocą uśredniania ocen wystawianych przez innych badaczy.

Po raz pierwszy Cattell posłużył się spisem w celu badań statystycznych psychologów. W 1903 r., gdy spis był dopiero przygotowywany, przyjrzał się wybranej grupie dwustu psychologów i analizował ich „akademickie pochodzenie [instytucje], drogę i przeznaczenie”. Badanie to zawierało elementy, które w kolejnych latach definiowały pracę Cattella: wyodrębnienie najlepszych naukowców, ukazanie ich efektywności, porównywanie ich pracy z badaczami z innych krajów i proponowanie odpowiednich działań. Cattell podzielił psychologów na cztery równe grupy według tego, co nazwał zasługami naukowymi. Na tej podstawie pokazał, że „różnice nie są ciągłe, ale istnieje tendencja do formowania się grup i rodzajów" (Cattell 1903: 315). Dwie główne grupy czy typy zostały wyodrębnione: „istnieją liderzy i osoby o przeciętnych osiągnięciach, ci pierwsi stanowią zaś około dziesięć procent wszystkich. Liderzy dzielą się z kolei na cztery grupy - powiedzmy, że wielkich geniuszy, zwykłych geniuszy, osoby o nieprzeciętnym talencie i osoby utalentowane" (Cattell 1903: 316).

Zidentyfikowawszy wybraną grupę psychologów, Cattell porównywał ich produkcję naukową z naukowcami z innych krajów za pomocą zliczania publikacji: „by porównać naszą produktywność z wynikami zagranicznych naukowców, policzyłem pierwsze tysiąc odniesień w indeksie dwudziestopięciotomowego Zeitschrift fur Psychologie” (Cattell 1903: 327). „Mówiąc ogólnie, wydaje się, że każdy z naszych psychologów wniósł wkład o jakimś znaczeniu, średnio jedynie raz na dwa czy trzy lata" (Cattell 1903: 328). Ogólnie rzecz biorąc, to Niemcy byli najbardziej produktywni. „Amerykanie zdecydowanie przewodzą w eksperymentalnym wkładzie w psychologię, nasz wkład teoretyczny jest mniej więcej taki sam, co Wielkiej Brytanii, zaś niemal dwukrotnie większy od nas mają Francuzi i Niemcy, wreszcie jesteśmy znacznie słabsi od Niemiec, Francji, Wielkiej Brytanii i Włochów jeśli chodzi o wkład w badaniach fizjologicznych i patologicznych" (Cattell 1903: 327328).

Cattell był pierwszym z wielu naukowców, którzy posłużyli się danymi dotyczącymi publikacji w celu dokonania pomiarów nauki w pierwszych dekadach XX wieku. Niedługo potem dołączyli do niego inni. Niniejszy artykuł dowodzi, że to 
amerykańscy psychologowie byli pionierami czynienia systematycznego użytku z bibliometrii. Przez bibliometrię rozumiem liczenie artykułów (i cytowań)‥ Z kolei przez „systematyczność” rozumiem regularny użytek ze zliczania artykułów dla określonego celu i przez nieprzerwany okres. Przed psychologami pojawiało się ono sporadycznie (John S. Billings), ale to dopiero oni uczynili z bibliometrii systematyczny użytek. Artykuł ten wyjaśnia, dlaczego to właśnie psychologowie zaangażowali się w bibliometrię i jak statystyki przyczyniły się do rozwoju psychologii.

Pierwsza część artykułu dokumentuje, jak psychologowie rozumieli status psychologii jako nauki oraz jak go bronili w końcu XIX wieku, a także przedstawia Cattella jako reprezentanta tej retoryki. Druga część analizuje, jak kilku psychologów, od początku XX wieku, zaangażowało się w mierzenie rozwoju w psychologii za pomocą recenzji i historiografii dyscypliny. Historiografie te i recenzje zawierały kilka statystyk, włączając w to statystyki publikacji. Dwoma centralnymi postaciami byli Edward F. Buchner i Samuel W. Fernberger. Ten drugi jest również kluczową postacią dla zrozumienia tego, jak zliczanie publikacji zaczęło służyć retoryce produktywności badań. Trzecia część omawia te wysiłki, uwzględniając pionierską pracę opublikowaną przez Shepherda I. Franza. Ostatnia część analizuje pierwsze wykorzystanie bibliometrii do studiów nad społecznością akademicką jako całością, a nie tylko do badań psychologicznych, i pokazuje, że zainteresowanie kreatywnością stało za takimi inicjatywami, jak te podjęte przez Harveya C. Lehmana i Wayne'a Dennisa.

Artykuł ten, do pewnego stopnia, jest wkładem w historię nauki. Kilku autorów udokumentowało już wysiłki naukowców na rzecz instytucjonalizacji nauki w XIX wieku. Przyglądając się organizacjom szczególnie zaangażowanym w rozwój nauki, analizowali np. różne strategie przyjmowane przez naukowców, jak i formy, które ta instytucjonalizacja przyjmowała (Kohlstedt 1976; MacLeod i Collins 1981; Kohlstedt, Sokal i Lewenstein 1999; Gispert 2002). Artykuł ten, wraz z poprzednim (Godin 2007), uzupełnia o zbiór statystyk nauki retoryczny arsenał środków przyczyniających się do jej rozwoju. Stanowi również wkład w istniejącą literaturę poświęconą wypracowywaniu granic (boundary-work). Kilku naukowców przyjrzało się metodom, zarówno eksperymentalnym, jak i statystycznym, i ich roli w rozgraniczaniu dyscyplin ${ }^{2}$. Tu dokumentujemy szczególny typ statystyk, dotyczących samej dyscypliny (liczby profesorów, studentów, publikacji itd.) oraz ich roli w rozwoju psychologii. Jak zasugerował Cattell, „przedmiotowe zagadnienia (psychologii) były uzupełniane przez filozofię i metody nauk przyrodniczych" (Cattell 1898a: 535). To napięcie znajdowało się w samym sercu użytku, jaki psychologowie czynili ze statystyk, oceniając osiągnięcia psychologii jako nauki.

\footnotetext{
${ }^{1}$ Dyskusja wokół pojęć: Hood i Wilson 2001.

${ }^{2} \mathrm{O}$ wypracowywaniu granic (boundary-work) i szczególnej roli statystyki: Amsterdamska 2005.
} 


\section{Status psychologii jako nauki}

Wykorzystanie przez Cattella danych z American Men of Science miało na celu rozwój nauki. Jego zdaniem warunki, w których znalazła się nauka w Ameryce, były niekorzystne dla badań. Ludzie nauki byli bardziej zajęci dydaktyką niż badaniami, a pensje aktywnych badaczy były zbyt niskie. Cattell ocenil, że osoby zaangażowane w badania „nie poświęcają im więcej niż średnio połowę czasu, którym dysponują” (Cattell 1910a: 633). Mówiąc ogólnie, „człowiek, który nie poświęca swojej pracy więcej niż połowę czasu, musi być postrzegany jako amator" (Cattell 1917: 281). Zdaniem amerykańskiego psychologa „wybitni ludzie odczuwali brak, którego źródeł należy doszukiwać się w zmianach w otoczeniu społecznym” (Cattell 1910a: 646): rosnącej złożoności nauki, metodach edukacyjnych, braku stypendiów i asystentur, ale również w braku nagród, obciążeniu dydaktycznym i niskich zarobkach. „Pensje i nagrody nie są dostosowane do osiągnięć”, w przeciwieństwie do Niemiec, Wielkiej Brytanii i Francji, gdzie „wybitni ludzie cieszyli się szczególnym szacunkiem [...]. Powinno się stworzyć metody, które pozwolą na wynagradzanie pracy naukowej zgodnie z jej wartością dla społeczeństwa - wcale nie w interesie badacza, ale społeczeństwa" (Cattell 1910a: 648). Przez trzydzieści lat Cattell publikował statystyki dotyczące demografii i geografii naukowców, by pokazać ten stan rzeczy i wnieść wkład w rozwój nauki (Godin 2007).

Statystyki nauk psychologicznych były zbierane w tym konkretnym celu: wnieść wkład w rozwój psychologii. Jednak retoryka była inna. W tym przypadku Cattell i inni psychologowie nie krytykowali swoich warunków pracy, a raczej z przekonaniem argumentowali, że psychologia była faktycznie jedną z nauk. Podczas gdy punktem odniesienia, za pomocą którego oceniano profesję akademicką w Ameryce, była Europa, ciesząca się uznaniem dzięki swoim katedrom, laboratoriom i wsparciu publicznemu, w przypadku nauk psychologicznych to status vis-à-vis innych nauk, eksperymentalnych w swojej naturze, służył jako jej miara.

W kilku odezwach do swoich kolegów po fachu Cattell podjął się udokumentowania „przeobrażania się psychologii w naukę konkurującą w aktywności i owocności z innymi wielkimi naukami” (Cattell 1898a: 541). Pierwsza taka deklaracja złożona przed Amerykańskim Towarzystwem Psychologicznym, ukazała się w $1896 \mathrm{r}$. „W walce o przetrwanie, która toczy się w nauce, psychologia wciąż umacnia swoją pozycję” (Cattell 1896: 134), twierdził Cattell. „Akademicki rozwój psychologii w Ameryce w ostatnich latach jest bezprecedensowy". Według Cattella ten postęp psychologia zawdzięczała metodom: „Pomiary mają takie same miejsce w psychologii jak w naukach empirycznych [...] Pomiary stanowią część opisu, i to tę najdokładniejszą, najbardziej uniwersalną i wydajną metodę opisu, jaką dotychczas stworzono" (Cattell 1896: 140). Cattell miał tu na myśli dane, średnie i błędy sta- 
tystyczne: „Teoria prawdopodobieństwa, pozwalająca nam mierzyć zarówno naszą wiedzę, jak i poziom ignorancji, jest jednym z wielkich osiągnięć ludzkiego intelektu, możliwym do wykorzystania również w naukach utrzymujących różne stopnie dokładności" (Cattell 1896: 142).

Dwa lata później, w innej odezwie (przed AAAS), Cattell był bardziej pewny siebie, nawet arogancki. Omówił najpierw, jak w ciągu pięćdziesięciu lat „psychologia wykazała się niezwykłą żywotnością [i stała się] dyscypliną uniwersytecką" (Cattell 1898a: 534). Jako dowód przedstawił prace uznanych amerykańskich psychologów, takich jak William James, Granville C. Hall i George T. Ladd, i opowiadał o laboratoriach, wydziałach, czasopismach i pracy Amerykańskiego Towarzystwa Psychologicznego. Wypowiedź miała na celu postawienie psychologii na szczycie hierarchii dyscyplin. Już w 1896 r. Cattell zasugerował, że eksperymentalna psychologia ma praktyczne zastosowanie w „edukacji, medycynie, sztukach pięknych, ekonomii politycznej, a w rzeczy samej w procesie życia jako całości” (Cattell 1896: 144) i dzięki swoim metodom obserwacji i eksperymentów, które ustanawiają „,tandardy ostrożności i obiektywności” (Cattel 1896: 145), nawiązała relację z innymi naukami: fizyką, fizjologią i biologią (Cattell 1896: 147-148). W ten sposób psychologia stała się matką wszystkich nauk. „Psychologia nie jest nową nauką”, argumentował Cattell, wręcz „powinna być uznana za jedną z najstarszych nauk” (Cattell 1898a: 535). „W porównaniu z psychologią nauka taka jak astronomia może wydawać się niemal naiwna. Całe funkcjonowanie Układu Słonecznego i gwiazd stałych, znane już od czasu Chaldejczyków, jest mniej skomplikowane niż przedszkolna zabawa dziecka w ciągu jednego dnia [...]. Atomy i molekuły są tak niewidoczne, eter jest tak nienamacalny i wiemy w końcu o nich tak mało, że łatwo wymyślać hipotezy” (Cattell 1898a: 538). Kontynuował: „Dwie największe naukowe generalizacje naszego stulecia to zasada zachowania energii i ewolucja przez przetrwanie najsilniejszych. Załóżmy jednak, że świadomość, choćby nawet $\mathrm{w}$ niewielkim stopniu, modyfikuje pozycjonowanie cząsteczek w mózgu, fundamentalne założenie nauk fizycznych zostaje obalone. Jeśli świadomość nie ma nic wspólnego z działaniami indywiduum, jeden z najbardziej skomplikowanych efektów ewolucji rozwinął się niezależnie od przetrwania użytecznych różnic, a więc teoria Darwina upada. [...] Świat jest tylko jeden; każda jego część pozostaje w relacji do innej części i każda z części zawiera się w tych relacjach" (Cattell 1898a: 540).

Dla Cattella „nie istnieje dział wiedzy czy aktywności, który nie miałby czegoś wspólnego z psychologią i jeśli dotychczas to psychologia uczyła się od innych nauk, poprzedzających ją w swoim rozwoju, nadejdzie czas, a być może już nadszedł, gdy każda z nauk będzie musiała wziąć pod uwagę fakty i teorie psychologii” (Cattell 1898a: 538-539). Następnie podawał przykłady, w których psychologia łączy się z matematyką, mechaniką, fizyką, fizjologią, chemią, geologią, geografią, biologią, 
antropologią, literaturą i sztukami pięknymi. „Błędy w obserwacji, równanie specyfikacyjne, stosunek pomiędzy umysłowym a fizycznym natężeniem to tematy, które wymagają zastosowania dociekań prowadzonych w laboratoriach psychologicznych do astronomii i innych nauk fizycznych” (Cattell 1898a: 539). Mówiąc ogólnie, „psychologia stała się integralną częścią współczesnej nauki [...]. Jej pozycja w korpusie nauki jest zatem zabezpieczona" (Cattell 1898a: 540)3.

W swoich przemówieniach Cattell wykorzystywał niektóre statystyki, ale to Burt G. Miner z Uniwersytetu w Illinois zaprezentował bardziej systematyczne dane. W artykule opublikowanym na łamach Science w 1904 r. Miner ogłosil, że „na kolejnych stronach autor przedstawia pewne fakty, które dają dowód na rozwój psychologii w amerykańskich instytucjach szkolnictwa wyższego, z nadzieją na zaprezentowanie bardziej adekwatnych środków do oceny obecnego statusu tej nauki” (Miner 1904: 299-300). Dane pochodziły ze spisów 150 koledży i informacji dostarczonych przez dyrektorów 34 uznanych laboratoriów. Miner przedstawił statystyki dotyczące laboratoriów, ich liczbę i użyteczność podzielone na trzy kategorie zgodnie z wyposażeniem i aparaturą. Pokazał również dane dotyczące dochodów i przestrzeni poświęconej psychologii na uniwersytetach. Przyjrzał się katedrom, wydziałom i ich zakładom czy specjalizacjom, profesorom, zajęciom i dydaktyce. Oszacował, że 20\% osób w procesie rekrutacji na uniwersytet wybrało psychologię i że „60\% studentów podyplomowych z większych amerykańskich uniwersytetów wybrało przynajmniej jeden przedmiot wprowadzający do psychologii” (Miner 1904: 302). Próbował stworzyć również coś na ksztalt rankingu uniwersytetów (pomysł ten rozwinął następnie Cattell), opartego na liczbie doktorantów, jak i podjął temat zalet metod ilościowych w psychologii za pomocą rekrutacji na zajęcia laboratoryjne i badań nad składem osobowym laboratoriów. Dla Minera „mało które dziedziny nauki mogą się wykazać podobnymi osiągnięciami i z całą pewnością żaden inny kraj nie dorównuje Stanom Zjednoczonym w liczbie [63] gorliwych badań psychologicznych" (Miner 1904: 303).

${ }^{3}$ Ponad trzydzieści lat później Cattell wciąż posługiwał się tą samą formą dyskursu. W artykule poświęconym „ekonomicznej wartości psychologii [i] jej pożyteczności dla współczesnej cywilizacji” Cattell przedstawił przedmiot psychologii jako „kontrolowanie zachowań jednostek”. Dla niego „do zadań psychologii należy ocena tego, co tak naprawdę działa na korzyść rasy ludzkiej”: selekcjonowanie, ćwiczenie i kierowanie człowiekiem (Cattell 1930: 286). „Studia i praktykowanie medycyny i inżynierii będą znacznie bardziej rozwinięte, kiedy uświadomimy sobie, do jakiego stopnia powinny one opierać się na rozumieniu i kontrolowaniu zachowania” (Cattell 1930: 286). „Kontrola myśli, emocji i zachowania podjęta została przez kościoły, szkoły, prawo i resztę w celu osiągnięcia określonych celów, które postrzegane są jako pożądane, w większości jednak zawiodły, gdyż nie jest łatwo zmienić naturę ludzką” (Cattell 1930: 286-287). „Psychologia może osiągnąć więcej, sytuując jednostki w otoczeniu, w którym będą działały w sposób oczekiwany, niż przez usiłowanie zmiany samych jednostek" (Cattell 1930: 286). 
Tabela 1. Pierwsze kroki na drodze instytucjonalizacji psychologii w Stanach Zjednoczonych

\begin{tabular}{|l|c|c|}
\hline Pierwsze laboratorium & Johns Hopkins University (Hall) & 1883 \\
\hline Pierwsze czasopismo & American Journal of Psychology & 1887 \\
\hline Pierwszy wydział & University of Pennsylvania (Cattell) & 1888 \\
\hline Towarzystwo & Amerykańskie Towarzystwo Psychologiczne & 1892 \\
\hline Pierwszy indeks & Psychological Index & 1895 \\
\hline
\end{tabular}

Źródło: opracowanie własne.

Zarówno dla Cattella, jak i Minera psychologia, choć była bardzo młodą dyscypliną, posiadała już status dyscypliny naukowej. Prowadzenie statystyk tej profesji stanowiło jedną z istotnych części strategii uczynienia z psychologii nauki. Dowody ilościowe prezentowane były na temat każdego aspektu dyscypliny i jej instytucjonalizacji: profesorów, wydziałów, programów kształcenia, rekrutacji studentów i doktorantów, laboratoriów, czasopism i pracy Towarzystwa.

\section{Sporządzanie bilansu rozwoju}

Tego rodzaju retoryka posłużyła za model innym psychologom i ich posługiwaniu się statystykami. W następnych dekadach kilku psychologów rozwinęło retorykę postępu w psychologii, w których miary rozwoju były oparte na samych psychologach (ich liczbie, rozmieszczeniu geograficznym, liczbie na milion mieszkańców, statusie i stopniu naukowym), programach kształcenia, przyznanych doktoratach, laboratoriach, czasopismach i... publikacjach. Dane te były dostarczane na dwa sposoby: pierwszy to raporty okresowe. Część z nich miała wymiar wyłącznie jakościowy ${ }^{4}$, ale kilka posiadało również komponent ilościowy. Raporty ukazywały się okazjonalnie (tak było w przypadku Cattella, Edwina G. Boringa, Christiana A. Ruckmicha i Colemana R. Grifitha), część z nich była jednak przygotowywana bardziej systematycznie, stanowiąc część rocznych (Edward F. Buchner) bądź dziesięcioletnich (Samuel W. Fernberger) serii. Drugim medium określania postępu w psychologii były historie Towarzystwa (Fernberger).

Założyciel Southern Society for Philosophy and Psychology, E. F. Buchner z Uniwersytetu w Alabamie, zainicjował pierwszą serię raportów dotyczących psychologii w 1904 r. Rok wcześniej w następujący sposób wyłożył swoje racje: pięćdziesiąt lat temu, pisał, „psychologia była powszechnie uważana za przybłędę i nie interesowała badaczy faktów; przyszła na świat ostrożnie, powołana przez wielkich po-

${ }_{4}$ Zob. przykłady w: Titchener 1905; 1910. 
szukiwaczy kategorii świata. Rewolucja, która wydała »naukową« psychologię, jak będą musieli odnotować historycy, postępowała w dwóch kierunkach” (Buchner 1903b: 194). Pierwszym i najważniejszym z tych kierunków była metoda: „Rozwinęła ogólny typ metody, która opracowała wielką zmianę ze spekulatywnej obrony aplikacji określonych interpretacji teoretycznych każdego rodzaju doświadczenia wewnętrznego na faktyczne indukcyjne, mierzalne, eksperymentalne podejście [...]” (Buchner 1903b: 194). Dla Buchnera „w przeszłości, amerykańska psychologia żeglowała pod banderą »filozofii moralnej i filozofii umysłu« [...]. Ona również była formowana głównie przez teologów" (Buchner 1903a: 194). Teraz amerykańska psychologia „wyrzeka się naszego dawnego intelektualnego podporządkowania jakimś obcym systemom czy też jakiemuś myślicielowi ze Starego Świata” (Buchner 1903b: 194-195).

Następnie Buchner zrecenzował pracę Amerykańskiego Towarzystwa Psychologicznego i jego wpływu, przede wszystkim laboratoriów, katedr i systematycznych publikacji jego członków. Poświęcił również znaczną część zagadnieniu organizacji psychologii, to znaczy Towarzystwu i jego pracy od 1892 do 1901 r. Przyglądał się członkom i spotkaniom: frekwencji, wystąpieniom prezesów Towarzystwa, przedstawianym artykułom. Pogrupował 283 artykuły według dwóch klasyfikacji: 1) kategorii i podkategorii Psychological Index z 1895 r., 2) tematów takich, jak metody, zainteresowania i rezultaty. Obliczył również liczbę artykułów przypadających na jednego członka Towarzystwa i dostrzegł tendencję, która wiele lat później została sformalizowana w postaci prawa (Lotka 1926; Bradford 1934): „89 członków stanowiło całość autorów, trzydziestu czterech zaprezentowało jeden jego element w postaci artykułu, raportu itd.; trzydziestu trzech zaprezentowało dwa elementy, dziesięciu - trzy; ośmiu - cztery; pięciu - pięć; trzech - sześć; dwóch - czternaście; jeden - siedemnaście; kolejny - dziewiętnaście i wreszcie jeden zaprezentował dwadzieścia trzy. Pozostałych pięćdziesięciu dziewięciu członków było nieaktywnych, płacąc wyłącznie coroczne składki. Jest to doprawdy ważkie pytanie: czy Towarzystwo może przyspieszyć swój rozwój, ciągnąc czterdziestoprocentowy martwy ciężar [...]” (Buchner 1903b: 204).

W 1904 r. Buchner rozpoczął zatem serię raportów z psychologii pt. Psychological Progress, w celu „sporządzenia bilansu naszego postępu”, to znaczy „ocenie sposobu zarządzania i szacowania wyników końcowych wszystkich podejmowanych wysiłków" (Buchner 1904: 57). Seria ukazywała się co roku w Psychological Bulletin od 1904 do 1913 r. Zawierała omówienia ostatnich artykułów, ale także dane ze spisu Cattella dotyczące liczby psychologów w kraju i z serii w Science dotyczących przyznanych doktoratów, listy nowych czasopism i statystyk publikacji. Począwszy od drugiej odsłony raportów (1905), prezentowano procentowy rozkład artykułów ukazujących się w Psychological Index. Służyło to ocenie zainteresowania psychologów danymi tematami. Dla Buchnera zliczanie publikacji dostarczało „dobrej miary rocznego wahania intensywności zainteresowania standardowymi 
tematami zajmującymi psychologów" (Buchner 1905: 97). Podobnie jak wielu psychologów, którzy w kolejnych latach opracowywali takie statystyki, Buchner był dumny z mierzenia postępu w metodach eksperymentalnych: „Gdy szukamy cech psychologii, które pojawiły się w naszym kręgu, okazuje się, że rozwinęły się przez oddanie pomiarom, wyliczeniom i porównaniom jako efektywnym metodom ustalania elementarnych faktów życia wewnętrznego i ich relacji” (Buchner 1905: 406).

W odsłonie raportu z $1907 \mathrm{r}$. Buchner zaczął mówić o zmianach w udziale w kategoriach wzrostów i spadków w „nakładach” (procentowym i rankingowym) w odniesieniu do lat poprzednich (Buchner 1907: 8). Pojęcie „wzrostów” i „spadków” zostało po raz pierwsze użyte w statystycznych studiach Cattella nad człowiekiem nauki, opublikowanych w 1906 r. (Cattell 1906). Pojęcie „produktywności”, użyte po raz pierwszy przez Cattella w $1896 \mathrm{r} .^{5}$, również pojawiło się w recenzjach Buchnera z 1908 r. (Buchner 1908: 10). W odsłonie z 1912 r. Buchner obliczył, że 3186 artykułów zostało napisanych przez 2514 autorów. Tym samym odnotował 10-proc. spadek od 1908 r. Buchner stwierdził na koniec, iż „o tym, że nauka ukonstytuowała się ponad wszelkimi wątpliwościami, świadczy uderzająca stabilność pisarskiej wydajności. Rozrost Indexu zbliża się do swojej granicy" (Buchner 1912: 5).

Psychologowie kontynuowali raporty Buchnera przez następne lata. W 1912 r. Christian A. Ruckmich z Cornell University opublikował pełen statystyk raport z 25 lat psychologii. Źródłem danych były katalogi uniwersyteckie i kwestionariusze wysłane do 39 instytucji. Uwzględniane były laboratoria, kursy, wydziały i ich warunki funkcjonowania, takie jak powiązania z innymi wydziałami. Artykuł podejmował również kwestię miejsca psychologii wśród innych nauk. Psychologia była porównywana (i zaliczana) do sześciu innych dyscyplin pod kątem liczby profesorów, godzin dydaktycznych, osób aplikujących i przyjętych na studia. Dyscyplinami tymi były ekonomia polityczna, edukacja, fizjologia, fizyka, filozofia i zoologia. Stworzony indeks miał agregować różne statystyki, jednak bez większego sukcesu. „Mówiąc ogólnie - podsumowywał Ruckmich na podstawie swoich wyliczeń - psychologia znajduje się na dole list częściej niż inne dyscypliny" (Ruckmich 1912: 529).

Ruckmich opublikował drugą analizę w 1916 r., gdzie włączył statystyki dotyczące publikacji, by spojrzeć na „produktywność nauki jako indeks jej stabilności i rozwoju" (Ruckmich 1916: 112). Wybrał sześć czasopism z lat 1905-1915 i policzył liczbę artykułów, liczbę stron każdego tekstu i rodzaje metodologii, jakimi się posługiwano. Artykuły zostały sklasyfikowane według 78 tytułów i podtytułów Psychogical Index. Niestety, Ruckmich w swoim tekście podał niewiele statystyk. Policzył ponad 800 publikacji obejmujących 20 tysięcy stron i przedstawił jedynie

${ }^{5}$ W swoim wystąpieniu z 1896 r. Cattell posłużył się pojęciem „produktywność”, by omówić produkcję akademicką psychologów: Amerykańskiego Towarzystwa Psychologicznego wydającego dwa czasopisma, wkład psychologów publikujących w wielu czasopismach w nauki ogólne, a „książki pisane przez członków Towarzystwa mają się dobrze wśród amerykańskich wkładów w naukę” (Cattell 1896: 135). 
rozkład artykułów i liczbę stron przypadających na metodę (eksperymentalną, nieeksperymentalną i spekulatywno-teoretyczną). Dla Ruckmicha liczby odzwierciedlały „wzrastającą produktywność” (Ruckmich 1916: 120).

To dopiero S.W. Fernberger z Uniwersytetu w Pensylwanii rozwiną statystyki dotyczące publikacji. Fernberger jest dziś znany ze stworzenia dwóch „klasycznych pozycji” w historii psychologii, jednej w 1932 r., drugiej w 1943 r. (Fernberger 1932; 1943). Przyjrzał się ewolucji członkostwa i wzrastającemu naciskowi na publikowanie jako jego kryterium, omówił kwestię finansów, czasopism Towarzystwa, organizacji i spotkań. Sporządził wykres liczby artykułów zaprezentowanych na każdym spotkaniu, począwszy od 1892 r., przyjrzał się „produktywności” uniwersytetów na tych spotkaniach, obliczając, że 19 uniwersytetów wyprodukowało 53\% wszystkich artykułów (Fernbereger 1943: 55), oraz temu, co nazwał konsekwencją w publikowaniu (czy też regularnością określoną w czasie: liczbą lat, przez które członkowie publikowali), polami zainteresowań i zainteresowaniami badawczymi.

W ramach pierwszego kroku w seriach swoich analiz Fernberger przyjrzał się Amerykańskiemu Towarzystwu Psychologicznemu, idąc w ślady E.G. Boringa. W 1920 r. Boring (z Clark University), jako sekretarz Amerykańskiego Towarzystwa Psychologicznego (1919-1922) i historyk psychologii (Boring 1929), opublikował geograficzne analizy członków Towarzystwa (Boring 1920). Posłużył się danymi pochodzącymi z Rocznika z 1920 r. i przygotował tabele przedmiotów nauczania podzielonych według geograficznych sekcji spisu, liczby psychologów przypadających na liczbę mieszkańców, pól badawczych, tytułów i pozycji akademickich. Wszystkie dane były podzielone według płci ${ }^{6}$.

Fernbereger kontynuowal te prace w kolejnych latach. Jego analizy Towarzystwa rozpoczęły się w $1921 \mathrm{r}$. (Fernberger 1921). Rozszerzył w nich badania Boringa o jeden dodatkowy wymiar - miejsca, w których kształcono amerykańskich psychologów, przedmiot szczegółowo badany przez Cattella od 1906 r. w odniesieeniu do całej profesji akademickiej. Dostrzegł względną koncentrację: pięć instytucji (Columbia, Chicago, Harvard, Clark i Cornell) przyznało w sumie 69,8\% wszystkich doktoratów, osiem - 85\%. W 1928 r., Ferberger uaktualnił wyniki Boringa i dokonał porównań dla lat 1920-1928 (Fernbereger 1928). Przyjrzał się geograficznemu rozmieszczeniu psychologów według stanów, miejsca edukacji, mobilności (lub chowu wsobnego), porównując miejsce edukacji z miejscem pracy, zajmowaną pozycją, nauczanymi przedmiotami i liczbą psychologów przypadających na milion mieszkańców. Przyjrzał się również „zainteresowaniom” badawczym czy polom badań, tak jak zostały zgłoszone przez samych psychologów w Roczniku od 1918 r. ${ }^{7}$

Następnie, w 1930 r., Fernberger zaczął interesować się publikacjami jako miarą zainteresowań badawczych. W „poprzednim badaniu analizowaliśmy jedynie dane

\footnotetext{
${ }^{6}$ Inna statystyczna analiza z tego okresu: Griffith 1922.

7 Zob. Ferberger 1929.
} 
pochodzące z Rocznika, innymi słowy to, co psychologowie mówili o samych sobie. Obecna analiza usiłuje uniknąć tego możliwego źródła błędu i przestudiować, co o badawczej naturze ci badacze w rzeczywistości robili i publikowali” (Fernberger 1930: 526). Fernberger dysponował teraz bardziej „obiektywnym” źródłem. Co się stało później? Zanim spojrzymy na dane Fernbergera, warto omówić dwa czynniki odpowiedzialne za ten rozwój: pojęcie produktywności i Index jako miarę nauki.

\section{Czy rozwój był zadowalający}

W 1917 r. Shepherd I. Franz, profesor na Uniwersytecie George'a Washingtona (1906-1921) i dyrektor naukowy (1909-1919), a następnie dyrektor (1919-1924) laboratoriów Rządowego Szpitala dla Umysłowo Chorych, zwanego również Szpitalem Św. Elżbiety, przeprowadził badania naukowej produktywności psychologów. „W ciągu ostatnich kilku lat pojawiały się analizy rozwoju psychologii w różnych okresach [...]”, zauważy Franz. „[...] nie dowiadywaliśmy się jednak, dzięki komu rozwój psychologii był możliwy, czy powiększającej się liczbie zawodowych psychologów odpowiadał wzrost liczby i wartości publikowanych badań. Innymi słowy, choć dostrzeżono, że dokonał się postęp, jesteśmy daleko od oceny, czy wzrost ten był satysfakcjonujący i czy odpowiadał zwiększającej się liczbie psychologów" (Franz 1917: 197-198). W przypisie Franz zaznaczył, że „rozważanie tych spraw zostało na mnie niejako zrzucone w związku z obowiązkami redaktora" (rekomendowano tych, którzy wykazali się pewnymi osiągnięciami) (Franz 1917: 200).

Dla Franza wszystkie metody obliczania wartości wkładu indywidualnego (wybierania do władz uczelni, selekcji i awansu w ramach struktur uniwersyteckich) miały wady. „Możemy osiągnąć coś [bardziej] konkretnego za pomocą ustalenia, czy dana osoba ma jakiś wkład publikacyjny w rozwój psychologii. Jest to stosunkowo latwa metoda przynosząca pozytywne efekty. W niewielkim lub nawet żadnym stopniu nie zostawia miejsca na dyskrecjonalność badacza, opiera się wyłącznie na uwzględnieniu opublikowanego materiału [...]. Możliwe staje się również udzielenie odpowiedzi na pytanie: czy rozwój, mierzony za pomocą liczby publikacji, odpowiada liczbie osób, które zostały profesjonalnymi psychologami” (Franz 1917: 200).

Z listy członków Amerykańskiego Towarzystwa Psychologicznego Franz wybrał 84 nazwiska z 48 instytucji i przyjrzał się ich publikacjom (według Psychological Index) od 1906 do 1915 r. Przyjął sześć typów publikacji: monografie, artykuły, debaty, książki, recenzje i raporty ze spotkań. Dla Franza takie źródło danych było idealne: „za nieuwzględnienie na liście wszystkich publikacji danej osoby odpowiada wyłącznie ona sama" (Franz 1917: 201, przypis).

Franz dostrzegł stosunkowo stały wzrost publikacji na przestrzeni czasu (Franz 1917: 203). Produktywność (liczba publikacji przypadająca na jednego psychologa) wahała się jednak: „w ostatnich pięciu latach około 30\% tych, którzy wnosili jakiś 
wkład, publikowała trzy lub więcej artykułów etc. każdego roku” (Franz 1917: 204). Dla Franza te wskaźniki produktywności wymagały zastrzeżeń, gdyż niektórzy mogli nie być aktywni przez cały czas. Przyjrzał się więc „przyznaniu doktoratów jako dacie wyznaczającej moment, od którego można realistycznie oczekiwać publikacji” (Franz 1917: 204) oraz porównał rzeczywistą i oczekiwaną liczbę autorów. Dostrzegł zmniejszający się stosunek rzeczywistego wkładu do oczekiwanego (Franz 1917: 205). Sprawdzil, czy dotyczy to również publikacji, które miały odsłonić nowe fakty lub zaproponować nowe interpretacje (artykuły i monografie), i również tym razem dostrzegł spadek.

Wszystkie zaobserwowane przez Franza tendencje sprawdzały się w odniesieniu do wieku. Wyróżnił dwie grupy autorów: młode i starsze osoby, a kryterium znów stanowił rok przyznania doktoratu (przed czy po 1906 r.). Obliczyl, że osoby starsze były bardziej produktywne od młodych, ale stosunek liczby rzeczywistych do oczekiwanych publikacji był większy wśród młodych osób. Ta sama zależność pojawiła się, gdy skonstruował połączony indeks publikacji, przyznając „arbitralną” wartość każdemu z sześciu typów publikacji po to, by zamienić „heterogeniczność różnych typów publikacji w homogeniczność". Krzywa rozkładu osób starszych miała inny kształt niż w przypadku młodych. Dla Franza „nie powinno się zakładać [...], że ludzie ci nic nie robią dla rozwoju psychologii. Część z nich może pełnić funkcje redaktorów, część z nich stoi za pracami swoich podopiecznych, a jeszcze inni (jak Herbert Spencer) mogą przygotowywać się do wydania magna opera, które dopiero ujrzy światło dzienne. Wydaje się jednak nieprawdopodobne, by aż 40\% osób należących do starszej grupy było zaangażowana w akumulację materiału do rozwoju kosmologii, systemu psychologii, obszernej historii nauki czy innego projektu, który nie powinien być odkładany na bok na rzecz drobniejszego wkładu w postaci artykułów czy monografii” (Franz 1917: 215). „Autor czuje, że część tych tak zwanych "profesjonalnych «psychologów powinna być zaklasyfikowana jako dyletanci" (Franz 1917: 216). Podsumowując, „zwracamy uwagę czytelnika na zdrowy rozsądek niektórych towarzystw naukowych, które wymagają od swoich członków, by ci, jeśli chcą zachować członkostwo, wykazywali ciągłe zainteresowanie rozwojem ich nauki przez publikowanie" (Franz 1917: 219).

Zainteresowanie produktywnością było tylko jednym czynnikiem stojącym za zliczaniem publikacji jako wskaźnikiem rozwoju naukowego. Inne związane były ze źródłami danych. Podczas gdy amerykańskie nauki psychologiczne były do tej pory definiowane przez członków Towarzystwa i ich produkcję naukową, od 1917 r. to Psychological Index zaczął definiować (czy reprezentować) to, czym była psychologia $^{8}$ - psychologia jako nauka nie była już wyłącznie sprawą Towarzystwa czy tylko amerykańskim zjawiskiem, ale zagadnieniem międzynarodowym. Zaś psychologia

${ }^{8}$ O tym, jak mierzenie nauki za pomocą indeksów bibliograficznych daje określony obraz nauki, zob. Wouters 1997. 
miała tyle szczęścia, że posiadała Index, publikowany od 1895 r., który zbierał (niemal) wszystkie (istotne) tytuły wydawane każdego roku na świecie w zakresie psychologii. Index mógł posłużyć jako miara psychologii jako nauki ${ }^{9}$.

W tym samym roku co Franz (1917) Fernberger skupił się na międzynarodowych porównaniach, posługując się Psychological Index jako źródłem danych. Rozpoczął pisanie serii artykułów poświęconych produkcji naukowej różnych krajów pt. National Trends in Psychology. Publikowane były co dziesięć lat, od 1917 do 1956 r. Ponieważ Index nie uwzględniał miejsca zamieszkania autorów ani ich adresów, Ferberger użył w ich zastępstwie języka. Jego kategorie wyglądały następująco:

- niemiecki (wliczając Austrię i część Szwajcarii),

- francuski (wliczając Belgię i część Szwajcarii),

- włoski,

- angielski (od 1940 r. podzielony na poszczególne kraje) ${ }^{10}$,

- rosyjski (od 1936 r.),

- inne (od 1946 r. podzielone na 18 języków).

Fernbereger udokumentował hegemonię Niemiec w pierwszych dekadach XX wieku, a następnie jej schyłek: angielskie tytuły znalazły się na fali wznoszącej przy jednocześnie malejącej liczbie tytułów francuskojęzycznych. Dla Fernbergera „być może najbardziej uderzającym aspektem tych badań było dostrzeżenie absolutnej konieczności, by studenci psychologii - niezależnie od narodowości - posiadali znajomość niemieckiego i angielskiego w stopniu pozwalającym na łatwe czytanie ze zrozumieniem w tych językach" (Fernberger 1917: 150).

Na podstawie tych regularnych analiz Fernberger napisał dwa artykuły o „ekonomii politycznej” badań, jeden z nich, opublikowany w Science, przyglądał się efektom dwóch wojen światowych, polityce i nacjonalizmowi (publikowaniu we własnym języku) (Fernberger 1938a; 1946b). „Istotne wydaje się rozważanie niektórych aspektów krzywych jako skorelowanych z równoczesnymi politycznymi i ekonomicznymi wydarzeniami”, sugerował Fernberger (1938a: 84). Omówił, jak wojna w połączeniu z politycznymi (nazizm, faszyzm) i ekonomicznymi kryzysami wpłynęła na spadek liczby publikacji, ale również jak nacjonalizm i wzrost nacjonalistycznych sentymentów doprowadził do wzrostu w innych krajach (Włoszech, Rosji i mniejszych państwach). Dla Fernbergera „polityczne i ekonomiczne czynniki

9 Fernberger oszacował, że w latach 1895-1936 zindeksowano 156861 tytułów.

${ }^{10}$ Metoda, którą się posłużono, była następująca: „Metoda użyta w niniejszym badaniu polega w pierwszym kroku na sprawdzeniu nazwiska autora w nadziei, że zostanie ono rozpoznane i przypisane do konkretnego kraju. Jeśli jednak nazwisko nie zostało rozpoznane, poszukuje się nazwiska w listach członków amerykańskiego i brytyjskiego Towarzystwa Psychologicznego. Jeśli i to zawiedzie, sprawdza się Who's Who, International Blue Book, Who's Who in Education (amerykańskie wydanie) i podobne odnośniki biograficzne. Jeśli i to nie przynosi rezultatu, należy znaleźc kraj pochodzenia autora przez wskazówki obecne w tytule, abstrakcie czy publikacji, w której artykuł się ukazal" (Fernberger 1940: 296). 
[...] mają duży wpływ na liczbę publikacji naukowych [...]. Ogólnie rzecz biorąc, jak można się spodziewać, wojna i okresy depresji gospodarczej wykazują tendencję do zmniejszania się rozmiaru produkcji naukowej. Z drugiej strony, obecność nowego i wykrystalizowanego ideału politycznego i silnego scentralizowanego rządu, skłonnego do wspierania czy nawet subsydiowania badań, znacząco zwiększa rozmiar produkcji naukowej, tak jak ma to miejsce we Włoszech czy Rosji” (Fernberger 1938a: 90). Po czym kontynuował: „ale jeśli istnieje nowy ideał polityczny i silnie scentralizowany rząd, który niespecjalnie wspiera i subsydiuje badania, tak jak w przypadku Niemiec, rozmiar produkcji naukowej zdaje się zmniejszać. Wreszcie wzrost silnych uczuć nacjonalistycznych wyraźnie przyczynia się do publikowania w rodzimym języku, nawet jeśli taka publikacja, dla mniejszych krajów, musiała z konieczności zmniejszyć liczbę czytelników, do których była adresowana" (Fernberger 1938a: 90).

Ten sposób analizowania Indexu został użyty również w dwóch badaniach produktywności amerykańskich psychologów w dwóch kolejnych artykułach. W 1930 r. Fernberger przyjrzał się publikacjom w Psychological Index w okresie dziesięciu lat (1919-1928). Index zawierał 3768 przykładów wkładu badawczego wniesionego przez 482 psychologów. Fernberger zaobserwował różnice ze względu na płeć w tym, co określił „produktywnością”: „wzrostem liczby tytułów przyznanych mężczyznom za udane lata i brak dostrzegalnego wzrostu w przyznanych tytułach wśród kobiet. W przypadku żadnej z płci nie występuje wzrost liczby nadawanych tytułów porównywalny ze wzrostem członkostwa w tym samym czasie" (Fernberger 1930: 527). Wyniki były następujące: „średni wkład w okresie dziesięciu lat to 7.77 w przypadku mężczyzn i tylko $4.09 \mathrm{w}$ przypadku kobiet. Członkowie Towarzystwa byli średnio niemal dwukrotnie bardziej produktywni niż członkinie" (Fernberger 1930: 528). „Niemal 14 razy więcej mężczyzn niż kobiet opublikowało 10 lub więcej artykułów w tym samym okresie" (Fernberger 1930: 528). Co więcej, mężczyźni wykazywali się znacznie szerszymi zainteresowaniami (liczba pól, w ramach których dana osoba pracowała) ${ }^{11}$.

Fernberger przyjrzał się następnie kilku zmiennym i ich oddziaływaniu na produktywność: geograficzne rozmieszczenie, regularność publikacji, data przyznanego tytułu naukowego (,rezultaty pokazują większą produktywność ogółem w przypadku osób, które niedawno otrzymały tytuł, ale różnice są niewielkie”), miejsce otrzymania tytułu (średnia 6,91 artykułu na rok, przewyższona przez Cornell, Harvard i Chicago) i wielkość miasta: „ogółem miasta z populacją przekraczającą 250 tysięcy mieszkańców wykazują się największą produktywnością [...] (Fernberger 1930: 540). Jednak owocne badania [ponad 10 artykułów] można prowadzić niezależnie od wielkości miasta, w którym znajduje się prowadzący je badacz (Fernberger 1930: 541).

\footnotetext{
${ }^{11}$ Pomiary kobiet w psychologii: Fernberger 1939; Bryan i Boring 1944; 1946.
} 
W 1938 r. Fernberger ponownie zmierzył naukową produktywność amerykańskich psychologów. Dla Fernbergera „badanie opublikowanych materiałów może być jedyną obiektywną metodą pozyskiwania tej informacji” (Fernberger 1938b: 262). Przyjrzał się publikacjom zindeksowanym w Psychological Abstracts w latach $1932-1936^{12}$. Dostrzegł 587 osób odpowiedzialnych za 3963 tytuły lub średnią 6,75 na jednego członka (Fernberger 1938b: 269). Odnalazł również szeroki zakres „zmienności częstotliwości publikacji”: „22\% członków nie opublikowało nic, a jedna osoba opublikowała 49 tytułów, czyli średnio niemal 10 tytułów każdego roku" (Fernberger 1938b: 269). Porównał objętość publikacji akademików i nieakademików oraz dostrzegł, że ci pierwsi są dwuipółkrotnie bardziej produktywni: średnio 7,8 tytułów dla akademików przeciwko 3,1 (Fernberger 1938b: 277). W kwestii regularności publikowania obliczył, że 22\% psychologów nie publikuje nic, a 40\% członków „nie opublikowało nic tylko w ciągu jednego roku albo wcale”. Usiłował porównać zainteresowania naukowe, tak jak zostały określone w Abstracts do tych wskazanych przez członków w rocznikach z lat 1918-1937, klasyfikacje te jednak zbyt się różniły, by możliwe było ich sensowne porównanie.

Praca Fernbergera wykazywała sporą oryginalność. Idąc w ślady Franza, zaczął systematycznie mierzyć produktywność naukową za pomocą liczenia publikacji, posługując się przy tym Indexem ${ }^{13}$. Przyglądał się produktywności również z perspektywy międzynarodowej. To, co pozostało do zrobienia, to zastosowanie liczenia publikacji do wspólnoty akademickiej jako całości. To zadanie pozostawił jednak innym.

\section{Najbardziej twórcze lata człowieka}

W 1928 r. w American Journal of Psychology ukazał się artykuł pod pseudonimem Helen Nelson. Autorka krytykowała w nim pogląd wyrażany przez Roberta S. Woodwortha z Columbia University, który twierdził m.in., że „okres w życiu człowieka między 20. a 40. rokiem życia zdaje się być najbardziej sprzyjającym pomysłowości”. Dla Nelson „to, że lata między dwudziestym a czterdziestym rokiem życia są najbardziej produktywne dla rozumu, nie może budzić żadnych wątpliwości. Jednak ograniczaniu wytworów rozumu do tego okresu zaprzecza sam rozum” (Nelson 1928: 303).

${ }^{12}$ Począwszy od 1936 r., Fernberger korzystał z Psychological Abstracts jako następcy niekontynuowanego już Psychological Index.

${ }^{13}$ Inne studia przeprowadzane w tym samym czasie za pomocą Indexu (lub Abstracts) nad zainteresowaniami badawczymi: Goodenough 1934; Hunter 1941. Studia nad zainteresowaniami naukowymi wciąż używały próbki „najlepszych” czasopism jako ocenianych przez badaczy (Allport 1940; Bruner i Allport 1940). 
Publikacja ta rozpoczęła całą serię badań nad kreatywnością naukowców, podjętych przez psychologów w następnych dekadach. Psychologowie zaczęli przyglądać się naukowcom ze wszystkich dziedzin, nie tylko swoim kolegom po fachu. Tym samym dołączyli do „studiów nad nauką”. Liczenie publikacji było jedną z metod mierzenia kreatywności (innymi były kwestionariusze i testy wydajności). Harvey C. Lehman z Ohio University był najbardziej aktywnym autorem, pracującym nad tym zagadnieniem przez ponad dwadzieścia lat ${ }^{14}$. Szczególnie interesowała go pytanie: „W którym roku życia osoby stworzą prawdopodobnie swoje najwybitniejsze dzieło?” (Lehman 1936). Przyjrzał się sztuce, literaturze, filozofii i nauce. Posłużył się historiami, biografiami i wprowadzeniami do mierzenia wybitnych dzieł (publikacji, pomysłowości). We wszystkich swoich badaniach Lehman potwierdził pogląd Woodwortha. Poszedł jednak dalej. W Man's Most Creative Years, wydanej w 1944 r., Lehman zadał pytanie o związek ilości z jakością, tak jak mierzone to było w jego źródłach. Odpowiedź była negatywna. Jeszcze raz posługując się zróżnicowanymi źródłami, sporządził wykres stosunku wieku do produktywności w jedenastu dyscyplinach od nauki i wynalazków po poezję i muzykę, podsumowując ,jakość twórczości i ilość twórczości nie jest koniecznie ze sobą skorelowana, twórczość najlepszej próby ma tendencję do obniżania się w porównaniu do mniej znaczącej twórczości" (Lehman 1944: 392).

W podobny sposób Wayne Dennis (Brooklyn College) przyjrzał się uznanym naukowcom i ich produkcji naukowej. Posługując się Biographical Memoirs Narodowej Akademii Nauk Stanów Zjednoczonych, Dennis zauważył 41 osób, których imiona pojawiały między 1943 a 1952 r. i które osiągnęły wiek 70 lat. Na podstawie biografii obliczył, że osoby te były odpowiedzialne za 8332 artykuły, czyli średnio 203 rocznie. Następnie przyjrzał się 25 najbardziej uznanym naukowcom XIX wieku na podstawie miejsca, jakie poświęcano im w encyklopediach i słownikach biograficznych, za pomocą metody nazywanej historiometrią ${ }^{15}$. Ustalił ich publikacje na podstawie Catalogue of Scientific Literature, 1800-190o, wydawanego przez Royal Society of London. Otrzymał odwrotne wyniki niż Lehman, mianowicie „wyraźny związek pomiędzy produktywnością a uznaniem w nauce [...]. Im większa liczba prac naukowych przygotowanych przez daną osobę, tym większe prawdopodobieństwo, że któraś z nich okaże się istotna” (Dennis 1954: 182). „W nauce ilość i jakość są ze sobą skorelowane" (Dennis 1954: 183).

W drugim badaniu Dennis zwracał uwagę na wiek, w którym naukowcy tworzą najwięcej. Znów uzyskał inne dane niż Lehman, koncentrując się na wszystkich typach publikacji, nie tylko na najlepszych. Wybrał z Webster's New International Encyclopedia (1930) 156 naukowców, którzy dożyli 70 lat lub przekroczyli ten wiek pomiędzy 1800 a 1900 r., a następnie policzył liczbę ich publikacji na podstawie

14 Kilka artykułów Lehmana zostało opublikowanych w: Lehman 1953.

15 „Historiometria jest tym dla historii, czym biometria jest dla biologii” - statystycznym badaniem człowieka za pomocą słowników i biografii (Wood 1909; 1911). 
Catalog of Scientific Literature. Obliczył, że „między 30. a 40. rokiem życia osiąga się wysoki przeciętny stopień produktywności [dwie publikacje w jednym roku], który utrzymuje się przez trzy dekady" (Dennis 1956: 724). Anne Roe, niezwykle aktywna psycholożka, która opublikowała kilka studiów z zakresu psychologii nauki w latach 50. i 60. XX wieku, potwierdziła utrzymywanie się publikacji na przestrzeni wielu lat w przypadku uznanych naukowców (Roe 1965a: 1972).

Ta fascynacja optymalnym wiekiem, w którym naukowcy tworzą swoje najistotniejsze prace, jest powtarzającym się tematem w naukach społecznych (Wyman 1919; Adams 1946; Manniche i Falk 1957; Zuckerman i Merton 1972; Cole 1979; Stephan i Levin 1992), była jednak tylko jednym z powodów, dla których analizowano wiek. Drugi był praktyczny, mianowicie reprodukcja „gatunku”. Wśród pierwszych zgromadzonych w historii statystyk poświęconych nauce wiele koncentrowało się na liczbie członków towarzystw naukowych, ich wieku w momencie ich wyboru i stopy umieralności. Były one motywowane ustanawianiem lub rewidowaniem zasad funkcjonowania akademii co do jej członków i przepisów dotyczących procedur elekcyjnych (Schuster 1925; Pearl 1925; 1926).

W latach 50. i 60. XX wieku amerykańskie studia psychologiczne nad naukowcami, ich kreatywnością i jej badaniem osiągnęły apogeum ${ }^{16}$. Często były przeprowadzane dzięki kontraktom z takimi instytucjami rządowymi, jak Office of Naval Research, Air Force, NASA czy National Institute of Health, lub też kontraktom pochodzącym z różnych gałęzi przemysłu i związanych z nimi stowarzyszeniami (takimi jak Industrial Research Institute). W tym samym czasie idea kreatywności zaczęła być kojarzona, czy też zrównywana, z „produktywnością”: zwykła liczba artykułów bądź stosunek autorów do artykułów. Zarówno zarządzanie badaniami, wydajność organizacji i czynniki odpowiedzialne za wydajność, jak i księgowość odpowiadały za te przekształcenia (Hogan 1950; Kaplan 1960; The Institution of Chemical Engineers 1963; Lipetz 1965; Seiler 1965; Yovits i in. 1966; Dean 1968). Psycholog Donald C. Pelz z University of Michigan był jednym z autorów odpowiedzialnych za ten ruch. Jego książka, napisana wspólnie z Frankiem M. Andrewsem i zatytułowana Scientists in Organizations, stała się na wiele lat klasyczną pozycją w dziedzinie zarządzania technologią (Pelz i Andrews 1966). Rozszerzając badania zainicjowane w latach 50. XX wieku (Pelz 1956), autorzy analizowali czynniki, warunki i środowisko, które najbardziej sprzyjały kreatywności czy produktywności w badaniach i innowacjach - swoboda, komunikacja, zróżnicowanie, oddanie, motywacja, satysfakcja, grupy oraz... wiek $^{17}$ - i tworzyli miary wydajności. Następ-

${ }^{16}$ Do najbardziej aktywnych psychologów należeli: Anne Roe, Calvin W. Taylor i Morris I. Stein. Zob. Roe 1951a; 1951b; 1952; 1953; 1963; 1964; 1965b; Taylor i Barron 1963; Taylor 1964a; 1964b; Taylor i Ellison 1967; Stein 1953; Meer i Stein 1955; Stein i Heize 1960; Stein 1962.

${ }_{17}$ Pelz potwierdził wyniki Lehmana, że okres między 30. a 40. rokiem życia jest tym produktywnym, ale zaobserwował bimodalną krzywą: istnieje drugi okres wzmożonej produktywności przypadający na okres między 50. a 60. rokiem życia. 
nie produktywność naukowa, określana jako produkowanie artykułów, stała się obiektem pomiarów dokonywanych przez socjologów (Meltzer 1949; 1956; Manis 1951; Ben-David 1960; Ben-David i Aran 1966; Crane 1965; Cole i Cole 1967; 1973; Allison i Stewart 1974; Allison, Long i Krauze 1982; Allison i Long 1990; Reskin 1977; Scott 1978; 1981) przede wszystkim za pomocą nowo opracowanego Science Citation Index (Garfield i Sher 1963). W końcu rozwinęła się cała wspólnota specjalistów w dziedzinie określanej bibliometrią.

\section{Wnioski}

Współcześnie wspólnota naukowa zajmująca się bibliometrią definiuje sama siebie w odniesieniu do prac autorów publikujących w latach 50. XX wieku, np. Wasilija V. Nalimova ${ }^{18}$, Eugena Garfielda ${ }^{19}$, a przede wszystkim Dereka J. de Solla Price'a ${ }^{20}$. Zresztą de Solla Price przyjrzał się kilku dyscyplinom, a nie tylko jednej, jak to miato miejsce w przypadku psychologii. Interesowało go mierzenie nauki w celu studiowania rozwoju wiedzy i jej praw, ówcześnie niezwykle aktualny temat (Lehman 1947; Weiss 1960; Holton 1962), szczególnie wśród bibliotekoznawców (Herner 1956) „obarczonych zarządzaniem ich kreaturą” (de Solla Price 1961: 104). Jego systematyczne badania były ściśle związane z wyłaniającym się polem studiów nad nauką. Ze wszystkich tych powodów de Solla Price musi być uważany za jednego z twórców bibliometrii (jak również naukometrii) w sensie, jaki nadał im Joseph Ben-David ${ }^{21}$. Istnieli jednak prekursorzy ${ }^{22}$. Kim byli?

Kilka „historii” bibliometrii przytacza prace bibliotekoznawców ${ }^{23}$ lub przekonuje, że to chemia stanowiła „awangardę tych głębokich przemian” w informatologii (Thackray i Brock 2000). Inni są nieco dokładniejsi (Meadows 2000), ale kompletna historia bibliometrii wciąż czeka na spisanie. Ogólnie rzecz biorąc, bardzo wczesne prace pochodzące z samego początku XX wieku są zapomniane albo wspominane wybiórczo i jakby w pośpiechu jako prehistoria ${ }^{24}$. Systematyczne wykorzystanie bibliometrii przez psychologów nigdy nie jest wspominane. W rzeczywistości jedynymi pracami psychologów, które są przywoływane w literaturze, są dwa okolicznościowe studia, opierające się lub zawierające analizowanie cytowań (Cason i Lubotsky 1936; Clark 1957). Dlaczego? Ponieważ autorzy twierdzą przeważnie,

\footnotetext{
${ }^{18}$ Zob. Scientometrics 2001.

${ }_{19}$ Zob. Cronin i Atkins 2000; Current Science 2005.

${ }_{20}$ Zob. Scientometrics 1985; Furner 2003.

${ }^{21}$ Ben-David dokonał rozróżnienia między prekursorami a założycielami, z których ci drudzy posiadali „uczniów” (Ben-David i Collins 1966).

${ }^{22}$ Przy tak rozumianej naukometrii Cattell jest założycielem, a nie prekursorem (Godin 2007).

${ }^{23}$ Zob. przykłady w: Broadus 1987; Wouters 1999.

${ }^{24}$ W celu znalezienia wyczerpującej bibliografii: Pritchard i Witting 1981.
} 
że „prawdziwa” historia zaczyna się wraz z Science Citation Index Garfielda i jego innowacją w systematycznym indeksowaniu cytowań. Jak twierdził sam Garfield: „»wskaźnik wpływu« może powiedzieć znacznie więcej niż kompletne wyliczenie liczby publikacji naukowców, którym posługiwali się Lehman i Dennis" (Garfield 1955: 109).

Z całą pewnością Science Citation Index był „pierwszą naprawdę poważną próbą uniwersalnej bibliograficznej kontroli nad literaturą naukową, począwszy od nowego stulecia" (Garfield 1964: 649). Musimy jednak rozróżnić dwa odmienne sposoby wykorzystania bibliometrii. Pierwszy to liczenie artykułów, którego psychologowie byli bez wątpienia prekursorami. Pomimo początkowo ograniczonego wykorzystania wyłącznie do własnej dyscypliny, systematyczne wykorzystanie publikacji jako wskaźnika dla nauki można wywodzić z psychologii. Inne zastosowanie bibliometrii to analiza cytowań. Kilku autorów przeprowadzało tego rodzaju analizy, począwszy od końca lat 20. XX wieku, łącznie z psychologami (Cason i Lubotsky 1936). To jednak Garfieldowi i jego Science Citation Index zawdzięczamy narzędzie, które pozwoliło na systematyczne studia nad cytowaniami.

Psychologowie nie byli metodologami bibliometrii. Mieli jednak świadomość ograniczeń statystyk publikacji. Fernberger zdawał sobie sprawę z wybiórczości źródła, jakim był Psychological Index, który źle indeksował literaturę niektórych krajów i nie uwzględniał wcale szarej literatury (Fernberger 1917: 144-145). Wspominał również o możliwości (nieznacznych) rozbieżności wynikających z opóźnień przy indeksowaniu (liczył artykuły zgodnie z datą publikacji w Indeksie, a nie według rzeczywistego roku wydania danego artykułu). Przede wszystkim wiedział, że „wartość” artykułów różni się od siebie i że nie uwzględnił „wartości wkładów przez różne kraje”, ale „zainteresowania psychologią” (Fernberger 1926: 202). Podobnie wczesne studia cytowań Casona i Lubotsky'ego jako mierzenia wpływu, a nie jakości: odniesienia pomiędzy czasopismami psychologicznymi są „ilościową miarą stopnia, w jakim każde pole psychologiczne wpływa i doświadcza wpływu innego pola psychologicznego" (Cason i Lubotsky 1936: 95). Można jeszcze wspomnieć o rozważaniach Franza nad frakcjonowaniem artykułów posiadających więcej niż jednego autora i decyzji, by przypisać „wspólny artykuł obu osobom i w każdym przypadku przypisać mu pełną wartość” (Franz 1917: 202).

Pomimo ograniczeń ich źródeł psychologowie byli całkiem pomysłowi. Podczas gdy Boring publikował jedną z pierwszych analiz (czy genealogii) psychologii (Boring i Boring 1948), Fernberger przeprowadził ankietę wśród absolwentów, by zmierzyć „prestiż i wpływ różnych psychologów”25. Poprosił 2288 studentów psychologii o „przejrzenie listy nazwisk i zaznaczenia na niej jednym symbolem znanych nazwisk, zaś dwoma tych nazwisk, których szczególny obszar kompetencji był

${ }^{25} \mathrm{Na}$ temat pierwszego badania (za pomocą kwestionariusza) prestiżu psychologów zob. Tinker, Thuma i Farnsworth 1927. 
znany badanym" (Fernberger 1954: 288). Porównał opinie studentów (rankingi) do obiektywnych miar, takich jak „produktywność”, w publikacjach, tak jak figurują w Psychological Register i w Psychological Abstract, i do gwiazd psychologii (spośród tysiąca najlepszych naukowców z American Men of Science) ${ }^{26}$. Doszedł do wniosku, że „tylko relatywnie niewiele osób zdawało się pozostawiać prawdziwie trwałe wrażenie [...]. Wśród najlepiej ocenianych psychologów w tym badaniu znaleźli się ci, których istotny wkład dokonał się w ostatnim czasie, jak i ci, którzy są postaciami historycznymi" (Fernberger 1954: 298). Dla Fernbergera wiek nie miał znaczenia. Wyróżnił trzy czynniki, które odpowiadały za wpływ i prestiż: liczbę publikacji, jakość opublikowanych prac i rodzaj wkładu (taki jak stworzenie nowego pola, wkładu do kilku istniejących pól czy rozwinięcie nowej metody).

To tylko część bibliometrycznych badań przeprowadzonych przez psychologów $^{27}$. Czemu psychologowie zaangażowali się w mierzenie nauki i jej produktywności? Jeden czynnik wywodzi się z samego pochodzenia dyscypliny. Psychologia eksperymentalna jest nauka empiryczną. W pierwszych laboratoriach psychologicznych psychologowie odczytywali pomiary dostarczane przez urządzenia i mierzyli czas reakcji czy też sądów sensorycznych, takich jak jasność czy rozmiar ${ }^{28}$. Następnie statystyka pojawiła się w dużej liczbie specjalizacji w psychologii: powstały kwestionariusze do badania osobowości, powstały testy wydajności i skale postaw, na bazie których rozwinęło się to, co nazywa się psychometrią (Hornstein 1988; Danziger 1990). Mierzenie samej psychologii jako dyscypliny było zatem małym i łatwym krokiem dla wielu psychologów. Jednak czynnik, który najbardziej wpłynął na użytek czyniony przez psychologów z liczenia publikacji, to krucjata na rzecz rozwoju psychologii jako nauki. To tutaj psychologowie mierzyli rozwój dyscypliny, korzystając ze wsparcia kolegi o nastawieniu eksperymentalnym i „ilościowym”, który służył sprawie rozwoju wszystkich nauk za pomocą statystyki przez ponad trzydzieści lat i który w 1906 r. stworzył pole naukometrii: Jamesa M. Cattella.

$\mathrm{Z}$ całą pewnością Cattell nie zajmował się specjalnie bibliometrią. Po artykule z 1903 r. policzył publikacje tylko dwa razy. Po raz pierwszy, gdy pojawiły się w jego przemówieniu z okazji 25-lecia Amerykańskiego Towarzystwa Psychologicznego w 1916 r. Cattell posłużył się w nim bibliometrią w niewielkim stopniu - opracował wykres artykułów zaprezentowanych na 25 spotkaniach Towarzystwa, a następnie wykazał istotny spadek tych o tematach historycznych, filozoficznych, analitycznych i introspekcyjnych i ogromny wzrost tych dotyczących pomiarów behawioral-

${ }^{26}$ Kilka lat później inny psycholog, Kenneth E. Clark, posłużył się podobną metodą, porównując cytowania razem z opiniami ekspertów i wskaźnikami uznania (Clark 1957).

${ }^{27}$ Psychologowie mierzyli również publikacje bibliografii, rozkład czasopism według krajów, liczbę rozdziałów i stron poświęconych różnym tematom w książkach i podręcznikach, jak również słowa w tytułach (Boring 1928; Davis i Gould 1929; Louttit 1929; 1931; Lauer 1931).

${ }^{28} \mathrm{Na}$ temat pierwszych list i statystyk amerykańskich laboratoriów zob. Delabarre 1894; Cattell 1898b; 1928; Ruckmich 1916; Garvey 1929. 
nych różnic indywidualnych (Cattell 1917). Nie rozstrzygnął jednak problemu postawionego we wstępie: „Możemy się zastanawiać, czy znaczenie pracy wykonanej w tym kraju na rzecz psychologii zwiększyło się w tym samym stopniu, co przyrost zaangażowanych w nią osób” (Cattell 1917: 279). Drugie wykorzystanie bibliometrii przez Cattella miało formę wystąpienia na dziewiątym Międzynarodowym Kongresie Psychologii na Yale University w New Haven w 1929 r. Cattell po prostu odtworzył dane Fernbergera, uaktualniając je o rok (Cattell 1929). Wkład Cattella w statystykę nauki to w takim razie nie bibliometria. Raczej za sprawą wielu raportów poświęconych psychologii jako profesji i jego licznych analiz statystycznych środowiska naukowego publikowanych na bazie jego spisu American Men of Science ${ }^{29}$, Cattell „nauczyl” swoich kolegów po fachu, jak używać statystyki na rzecz rozwoju profesji: „Jest to z całą pewnością czas na to, by naukowiec posłużył się naukowymi metodami [statystyką] do określenia okoliczności, które sprzyjają i utrudniają rozwój nauki”, regularnie sugerował Cattell (1910a: 634). Liczby „pokazują przewagę statystyki nad ogólnymi wyobrażeniami” (Cattell 1910a: 688). To „metoda obiektywna" (Cattell 1922, 688). Psychologowie go posłuchali, tym samym zapoczątkowując systematyczne korzystanie z bibliometrii.

przetożyt Jakub Krzeski

\section{Literatura}

Adams, C.W. (1946). The Age at Which Scientists Do Their Best Work. ISIS. 36: 166-169.

Allison, P.D., Long, J.S. (1990). Departmental Effects on Scientific Productivity. American Sociological Review. 55: 469-478.

Allison, P.D., Long, J.S., Krauze, T.K. (1982). Cumulative Advantage and Inequality in Science. American Sociological Review. 47: 615-625.

Allison, P.D., Stewart, J.A. (1974). Productivity Differences among Scientists: Evidence for Accumulative Advantage. American Sociological Review. 39: 596-606.

Allport, G.W. (1940). The Psychologist's Frame of Reference. Psychological Bulletin. 37(1): $1-28$.

Amsterdamska, O. (2005). Demarcating Epidemiology. Science, Technology, and Human Values. 30(1): 17-51.

Ben-David, J. (1960). Scientific Productivity and Academic Organization in Nineteenth-Century Medicine. W: J. Freudenthal (red.). Scientific Growth: Essays in the Social Organization and Ethos of Science (103-124). Berkeley: University of California Press. Ben-David, J., Aran, L. (1966). Socialization and Career Patterns as Determinants of Productivity of Medical Researchers. W: J. Freudenthal (red.). Scientific Growth: Essays in

${ }_{29}$ Po raz pierwszy badanie spisu zostało przeprowadzone na psychologach w 1939 r. przez geografa S.S. Vishera (Visher 1939). Można odnaleźć również tabele dostarczoną przez Cattella w: Kitson 1926. 
the Social Organization and Ethos of Science (71-89). Berkeley: University of California Press.

Ben-David, J., Collins, R. (1966). Social Factors in the Origins of a New Science. W: G. Freudenthal (red.). Scientific Growth: Essays in the Social Organization and Ethos of Science (451-465). Berkeley: University of California Press.

Boring, E. G. (1920). Statistics on the American Psychological Association in 1920. Psychological Bulletin. 17(8): 271-278.

Boring, E. G. (1928). Do American Psychologists Read European Psychology? American Journal of Psychology. 40(4): 674-675.

Boring, E. G. (1929). A History of Experimental Psychology. New York: Appleton-Century-Crofts.

Boring, M.D., E. G. Boring (1948). Masters and Pupils Among the American Psychologists. American Journal of Psychology. 61(4): 527-534.

Bradford, S.C. (1934). Sources of Information on Specific Subjects. Engineering. 137: 8586.

Broadus, R.N. (1987). Early Approaches to Bibliometrics. Journal of the American Society for Information Science. 38(2): 127-129.

Bruner, J.S., Allport, G.W. (1940). Fifty Years of Change in American Psychology. Psychological Bulletin. 37(10): 757-776.

Bryan, A.I., Boring, E.G. (1944). Women in American Psychology: Prolegomenon. Psychological Bulletin. 41(6): 447-456.

Bryan, A.I., Boring, E. G. (1946). Women in American Psychology: Statistics from the OPP Questionnaire. American Psychologist. 1(12): 71-79.

Buchner, E. F. (1903a). A Quarter Century of Psychology in America, 1878-1903. American Journal of Psychology. July-October: 402-416.

Buchner, E.F. (1903b). Ten Years of American Psychology, 1892-1902. Science. 18(450)14: 193-204, 18(451): 233-241.

Buchner, E. F. (1904). Psychological Progress. Psychological Bulletin. 1(3): 57-64.

Buchner, E. F. (1905). Psychological Progress in 1904. Psychological Bulletin. 2(3): 89-98.

Buchner, E. F. (1906). Psychological Progress in 1905. Psychological Bulletin. 3(4): 125-134.

Buchner, E.F. (1907). Psychological Progress in 1906. Psychological Bulletin. 4(1): 1-9.

Buchner, E.F. (1908). Psychological Progress in 1907. Psychological Bulletin. 5(1): 1-11.

Buchner, E.F. (1909). Psychological Progress in 1908. Psychological Bulletin. 6(1): 1-13.

Buchner, E. F. (1910). Psychological Progress in 1909. Psychological Bulletin. 7(1): 1-16.

Buchner, E. F. (1911). Psychological Progress in 1910. Psychological Bulletin. 8(1): 1-10.

Buchner, E. F. (1912). Psychological Progress in 1911. Psychological Bulletin. 9(1): 1-10.

Buchner, E.F. (1913). Psychological Progress in 1912. Psychological Bulletin. 10(1): 1-11.

Cason, H., Lubotsky, M. (1936). The Influence and Dependence of Psychological Journals on Each Other. Psychological Bulletin. 33(1): 95-103.

Cattell, J.M. (1896). Address of the President before the American Psychological Association, 1895. Psychological Review. 3(2): 134-148.

Cattell, J.M. (1898a). The Advance of Psychology. Science. 8(199): 533-554.

Cattell, J.M. (1898b). The Psychological Laboratory. Psychological Review. 5: 655-658. 
Cattell, J.M. (1903). Statistics of American Psychologists. American Journal of Psychology. 14: 310-328.

Cattell, J.M. (1906). A Statistical Study of American Men of Science III: The Distribution of American Men of Science. Science. 24(623): 732-742.

Cattell, J.M. (1910a). A Further Statistical Study of American Men of Science. Science. 32 (827): 633-648.

Cattell, J.M. (1910b). A Further Statistical Study of American Men of Science II. Science. 32 (827): 672-688.

Cattell, J.M. (1917). Our Psychological Association and Research. Science. 45(1160): 275284.

Cattell, J.M. (1922). The Order of Scientific Merit. Science. 56(1454): 547.

Cattell, J.M. (1928). Early Psychological Laboratories. Science. 67(1744): 543-548.

Cattell, J.M. (1929). Psychology in America. Science. 70(1815): 335-347.

Cattell, J.M. (1930). The Usefulness of Psychology. Science. 72(1864): 284-287.

Clark, K.E. (1957). America's Psychologists: A Survey of a Growing Profession. Washington: American Psychological Association.

Cole, S. (1979). Age and Scientific Performance. American Journal of Sociology. 84: 958977.

Cole, S., Cole, J.R. (1967). Scientific Output and Recognition: A Study in the Operation of the Reward System in Science. American Sociological Review. 32(3): 377-390.

Cole, J.R., Cole, S. (1973). Social Stratification in Science. Chicago: University of Chicago Press.

Crane, D. (1965). Scientists at Major and Minor Universities: A Study of Productivity and Recognition. American Journal of Sociology. 30(5): 699-714.

Cronin, B., Atkins, H.B (red.) (2000). The Web of Knowledge: A Festschrift in Honor of Eugene Garfield. Medford: ASIS Monograph Series.

Current Science (2005). Fifty Years of Citation Indexing. 89(9-10): 1502-1554.

Danziger, K. (1990). Constructing the Subject: Historical Origins of Psychological Research. Cambridge: Cambridge University Press.

Davis, R.A., Gould, S. E. (1929). Changing Tendencies in General Psychology. Psychological Review. 36(4): 320-331.

Dean, B.V. (1968). Evaluating, Selecting, and Controlling R\&D Projects. American Management Association.

Delabarre, E.-B. (1894). Les laboratories de psychologie en Amérique. L’Année psychologique. 1: 209-255.

Dennis, W. (1954). Bibliographies of Eminent Scientists. Science. 79(3): 180-183.

Dennis, W. (1956). Age and Productivity among Scientists. Science. 123(3200): 724-725.

Fernberger, S.W. (1917). On the Number of Articles of Psychological Interest Published in the Different Languages. American Journal of Psychology. 28(1): 141-150.

Fernberger, S. W. (1921). Further Statistics of the American Psychological Association. Psychological Bulletin. 18(11): 569-572.

Fernberger, S.W. (1926). On the Number of Articles of Psychological Interest Published in the Different Languages. American Journal of Psychology. 37(4): 578-581. 
Fernberger, S.W. (1928). Statistical Analyses of the Members and Associates of the American Psychological Association Inc. in 1928. Psychological Review. 35(6): 447-465.

Fernberger, S.W. (1929). Research Interests of American Psychologists. American Journal of Psychology. 412(1): 163-164.

Fernberger, S.W. (1930). The Publications of American Psychologists. Psychological Review. 37(6): 526-543.

Fernberger, S.W. (1932). The American Psychological Association: a Historical Summary, 1892-1930. Psychological Bulletin. 29(1): 1-89.

Fernberger, S.W. (1936). On the Number of Articles of Psychological Interest Published in the Different Languages. American Journal of Psychology. 48(4): 680-684.

Fernberger, S.W. (1938a). Publications, Politics and Economics. Psychological Bulletin. 35(2): 84-90.

Fernberger, S.W. (1938b). The Scientific Interest and Scientific Publications of the Members of the American Psychological Association. Psychological Bulletin. 35(5): 261-281.

Fernberger, S.W. (1939). Academic Psychology as a Career for Women. Psychological Bulletin. 36(4): 390-394.

Fernberger, S.W. (1940). A National Analysis of the Psychological Articles Published in 1939. American Journal of Psychology. 54(2): 296.

Fernberger, S.W. (1943). The American Psychological Association: a Historical Summary, 1892-1942. Psychological Review. 50(3): 33-60.

Fernberger, S.W. (1946a). On the Number of Articles of Psychological Interest Published in the Different Languages. American Journal of Psychology. 59(2): 284-290.

Fernberger, S.W. (1946b). Scientific Publications as Affected by War and Politics. Science. 104(2695): 175-177.

Fernberger, S.W. (1954). The Prestige and Impact of Various Psychologists on Psychology in America. American Journal of Psychology. 67(2): 288-298.

Fernberger, S.W. (1956). On the Number of Articles of Psychological Interest Published in the Different Languages. American Journal of Psychology. 69 (2): 304-309.

Franz, S.I. (1917). The Scientific Productivity of American Professional Psychologists. Psychological Review. 24(3): 197-219.

Furner, J. (2003). Little Book, Big Book: Before and After Little Science, Big Science: A Review Article. Journal of Librarianship and Information Science. 35(2): 115-125, 35(3): 189-201.

Garfield, E. (1955). Citation Indexes for Science: A New Dimension in Documentation Through Association of Ideas. Science. 122(3159): 108-111.

Garfield, E. (1964). Science Citation Index: A New Dimension in Indexing. Science. 144(3619): 649-654.

Garfield, E., Sher, I.H. (1963). Science Citation Index. Philadelphia: Institute for Scientific Information.

Garvey, C.R. (1929). List of American Psychology Laboratories. Psychological Bulletin. 26(11): 652-660.

Gispert, H. (2002). Par la science, pour la patrie: l'Association française pour l'avancement des sciences, 1972-1914. Rennes: Presses universitaires de Rennes. 
Godin, B. (2007). From Eugenics to Scientometrics: Galton, Cattell, and Men of Science. Social Studies of Science. 37(5): 691-728.

Goodenough, F. L. (1934). Trends in Modern Psychology. Psychological Bulletin. 31(2): 8197.

Griffith, C.R. (1922). Contributions to the History of Psychology, 1916-1921. Psychological Bulletin. 19(8): 411-428.

Herner, S. (1956). Technical Information: Too Much or Too Little. Science. 83(2): 82-86.

Hogan, R.M. (1950). Productivity in Research and Development. Science. 112(2917): 613616.

Holton, G. (1962). Scientific Research and Scholarship: Notes toward the Design of Proper Scales. Daedalus. 91: 362-399.

Hood, W.W., Wilson, C.S. (2001). The Literature of Bibliometrics, Scientometrics, and Informetrics. Scientometrics. 52(2): 291-314.

Hornstein, G.H. (1988). Quantifying Psychological Phenomena: Debates, Dilemmas, and Implications. W: J.G. Morawski (red.). The Rise of Experimentation in American Psychology (1-34). New Haven: Yale University Press.

Hunter, W.S. (1941). Research Interest in Psychology. American Journal of Psychology. 54(3): 606-607.

Kaplan, N. (1960). Some Organizational Factors Affecting Creativity. IEEE Transactions of Engineering Management. 30: 24-30.

Kitson, H.D. (1926). A Preliminary Personnel Study of Psychologists. Psychological Review. 33(4): 315-323.

Kohlstedt, S.G. (1976). The Formation of the American Scientific Community: The American Association for ther Advancement of Science, 1848-186o. Urbana: University of Illinois Press.

Kohlstedt, S.G., Sokal, M.M., Lewenstein, B.V. (1999). The Establishment of Science in America: 150 Years of the American Association for the Advancement of Science. London: Rutgers University Press.

Lauer, A. R. (1931). Why Not Re-Christen the "Psycho-Galvanic Reflex"? Psychological Review. 38(4): 369-374.

Lehman, H. C. (1936). The Creative Years in Science and Literature. The Scientific Monthly. 43(2): 151-162.

Lehman, H.C. (1944). Man's Most Creative Years: Quality versus Quantity of Output. The Scientific Monthly. 59(5): 384-393.

Lehman, H.C. (1947). The Exponential Increase of Man's Cultural Output. Social Forces. 25: 281-290.

Lehman, H.C. (1953). Age and Achievement. Princeton: Princeton University Press.

Lipetz, B.-A. (1965). The Measurement of Efficiency of Scientific Research. Carlisle: Intermedia.

Lotka, A.J. (1926). The Frequency Distribution of Scientific Productivity. Journal of the Washington Academy of Sciences. 16(12): 317-323.

Louttit, C.M. (1929). The Use of Bibliographies in Psychology. Psychological Review. 36(4): 341-347. 
Louttit, C.M. (1931). Psychological Journals: A Minor Contribution to the History of Psychology. Psychological Review. 38(5): 455-460.

Macleod, R., Collins, P. (1981). The Parliament of Science: The British Association for the Advancement of Science, 1831-1981 Northwood: Science Reviews.

Manis, J.G. (1951). Some Academic Influences upon Publication Productivity. Social Forces. 29: 267-272.

Manniche, E., Falk, G. (1957). Age and the Nobel Prize. Behavioral Science. 2: 301-307.

Meadows, J. (2000). The Growth of Journal Literature: a Historical Perspective. W: B. Cronin, H.B. Atkins (red.). The Web of Knowledge: A Festschrift in Honor of Eugene Garfield (87-107). Medford: ASIS Monograph Series.

Meer, B., Stein, M. I. (1955). Measures of Intelligence and Creativity. Journal of Psychology. 39: 117-126.

Meltzer, B. N. (1949). The Productivity of Social Scientists. American Journal of Sociology. 40: 25-29.

Meltzer, B.N. (1956). Scientific Productivity in Organizational Settings. Journal of Social Issues. 12: 32-40.

Miner, B.G. (1904). The Changing Attitude of American Universities Toward Psychology. Science. 20(505): 299-307.

Nelson, H. (1928). The Creative Years. American Journal of Psychology. 40: 303-311.

Pearl, R. (1925). Vital Statistics of the National Academy of Sciences. Proceedings of the National Academy of Sciences. 11: 752-768.

Pearl, R. (1926). Vital Statistics of the National Academy of Sciences. Proceedings of the National Academy of Sciences. 12: 258-261.

Pelz, D.C. (1956). Some Social Factors Related to Performance in a Research Organization. Administrative Science Quarterly. 1: 310-325.

Pelz, D.C., Andrews, F.M. (1966). Scientists in Organizations: Productive Climate for Research and Development. New York: John Wiley.

Pritchard, A.G., Wittig, G.R. (1981). Bibliometrics: a Bibliography and Index. Watford, Hertfordshire: ALLM Books.

Reskin, B. F. (1977). Scientific Productivity and the Reward Structure of Science. American Sociological Review. 42: 491-503.

Roe, A. (1951a). A Psychological Study of Eminent Biologists. Psychology Monographs. 65(14): 1-68.

Roe, A. (1951b). A Psychological Study of Physical Scientists. Genetic Psychology Monographs. 43(2): 121-239.

Roe, A. (1952a). A Psychologist Examines 64 Eminent Scientists. Scientific American. 187(5): 21-25.

Roe, A. (1952b). The Making of a Scientist. New York: Dood, Mead \& Co.

Roe, A. (1953). A Psychological Study of Eminent Psychologists and Anthropologists, and a Comparison with Biological and Physical Scientists. Psychology Monographs. 67(2): 1-55.

Roe, A. (1961). The Psychology of the Scientists. Science. 134(3477): 456-459.

Roe, A. (1963). Scientific Creativity. New York: John Wiley. 
Roe, A. (1964). The Psychology of Scientists. W: E. Mendelsohn i in. (red.). The Management of Scientists (49-71). Boston: Beacon Press.

Roe, A. (1965a). Changes in Scientific Activities with Age. Science. 150(3694): 313-318.

Roe, A. (1965b). Scientists Revisited. Harvard Studies in Career Development. 38. Graduate School of Education. Boston: Harvard University.

Roe, A. (1972). Patterns in Productivity of Scientists. Science. 176(4037): 940-941.

Ruckmich, C.A. (1912). The History and Status of Psychology in the United States. American Journal of Psychology. 23(4): 517-531.

Ruckmich, C.A. (1916). The Last Decade of Psychology in Review. Psychological Bulletin. 13(3): 109-120.

Ruckmich, C.A. (1926). Development of Laboratory Equipment in Psychology in the United States. American Journal of Psychology. 37(4): 582-592.

Solla Price, D.J. de (1961). Science since Babylon. New Haven: Yale University Press.

Schuster, A. (1925). On the Life Statistics of Fellows of the Royal Society. Proceedings of the Royal Society. A107: 368-376.

Scientometrics (1985). Derek John de Solla Price: Memorial Issue 7(3-6). Scientometrics (2001). V.V. Nalimov: Memorial Issue 52(2).

Scott, J.S. (1978). Productivity and Academic Position in the Scientific Career. American Sociological Review. 43(6): 889-908.

Scott, J.S. (1981). Organizational Context and Scientific Productivity. American Sociological Review. 46(4): 422-442.

Seiler, R.E. (1965). Improving the Effectiveness of Research and Development. New York: McGraw Hill.

Stein, M.I. (1953). Creativity and Culture. Journal of Psychology. 36: 311-322.

Stein, M.I. (1962). Creativity and the Scientists. W: B. Barber, W. Hirsh (red.). Sociology of Science (329-343 ). New York: Free Press.

Stein, M.I., Heinze, S.J. (red.) (1960). Creativity and the Individual. Glencoe: Free Press.

Stephan, P.E., Levin, S. G. (1992). Striking the Mother Lode in Science: The Importance of Age, Place, and Time. Oxford: Oxford University Press.

Taylor, C.W. (red.) (1964a). Creativity: Progress and Potential. New York: McGraw Hill.

Taylor, C.W. (red.) (1964b). Widening Horizons in Creativity. New York: John Wiley.

Taylor, C.W., Barron, F. (red.) (1963). Scientific Creativity: Its Recognition and Development. New York: John Wiley.

Taylor, C. W., Ellison, R. L. (1967), Biographical Predictors of Scientific Performance. Science. 155(3766): 1075-1080.

Thackray, A., Brock, D.C. (2000). Eugene Garfield: History, Scientific Information, and Chemical Endeavor. W: B. Cronin, H. B. Atkins (red.). The Web of Knowledge: A Festschrift in Honor of Eugene (11-23). Medford: ASIS Monograph Series.

The Institution of Chemical Engineers (1963). Productivity in Research, Proceedings of a Symposium held in London on 11-12 December 1963. London.

Tinker, M.A., Thuma, B.D., Farnsworth, P.R. (1927). The Rating of Psychologists. American Journal of Psychology. 38(3): 453-455.

Titchener, E.B. (1905). The Problems of Experimental Psychology. American Journal of Psychology. 16(2): 208-224. 
Titchener, E. B. (1910). The Past Decade in Experimental Psychology. American Journal of Psychology. 21(3): 404-421.

Visher, S. S. (1939). Distribution of the Psychologists Starred in the Six Editions of American Men of Science. American Journal of Psychology. 52: 278-292.

Weiss, P. (1960). Knowledge: A Growth Process. Science. 131(3415): 1716-1719.

Woods, F.A. (1909). A New Name for a New Science. Science. 30(777): 703-704.

Woods, F.A. (1911). Historiometry as an Exact Science. Science. 33(850): 568-574.

Wouters, P. (1997). The Signs of Science. W: B.C. Peritz, L. Egghe (red.). Proceedings of the Sixth Conference of the International Society for Scientometrics and Infometrics (491504). Jerusalem: School of Library.

Wouters, P. (1999). The Citation Culture [doctoral dissertation]. University of Amsterdam.

Wyman, W.I. (1919). Age of Production in Invention and Other Field. Journal of the Patent Office Society. 1: 439-446.

Yovits, M.C. i in. (red.) (1966). Research Program Effectiveness. New York: Gordon and Breach.

Zuckerman, H., Merton, R.K. (1972). Age, Aging, and Age Structure in Science. W: M.W. Riley i in. (red.). A Sociology of Age Stratification (292-356). New York: Sage.

\section{On the Origins of Bibliometrics}

ABSTRACT. Among the many statistics on science, called scientometrics, bibliometrics holds a privileged place. Bibliometrics is one of the few subfields concerned with measuring the output side of science. According to most "histories," bibliometrics owes its systematic development mainly to D.J. de Solla Price and Eugene Garfield, as founders. The few works conducted before the $1950 \mathrm{O}$ are usually relegated to prehistory. This paper documents how the systematic counting of publications originated with psychologists. In the early 1900s, psychologists began collecting statistics on their discipline. Publications came to be counted in addresses, reviews and histories of psychology for several decades. The aim was to contribute to the advancement of psychology. Far from being a negligible output of a prehistoric type, both the volume and the systematicness of these efforts are witnesses to what should be considered as pioneering work, and their authors considered as forerunners to bibliometrics.

KEYWORDS: bibliometrics, scientomerics, history of science, academic publications

CYTOWANIE: Godin, B. (2017). O początkach bibliometrii. Tłum. J. Krzeski. Nauka i Szkolnictwo Wyższe. 1(49): 19-46. doi: 10.14746/nisw.2017.1.1. 